\title{
Prevalence of Subclinical Mastitis in the Local Goats in the Province of Laghouat (ALGERIA)
}

\author{
Achour YAHIA ${ }^{1 *}$, Djelloul MREZGUI ${ }^{1}$, Khadidja HAMRAT ${ }^{2}$ and Rachid KAIDI ${ }^{1}$ \\ ${ }^{1}$ Laboratory of Biotechnology related to Animal Reproduction, Veterinary Sciences Institute, University \\ of Blida 1. Algeria. \\ ${ }^{2}$ Directorate of Agricultural Services, Blida. Algeria \\ achourveto@yahoo.fr
}

Bulletin UASVM Veterinary Medicine 73(2) / 2016,

Print ISSN 1843-5270; Electronic ISSN 1843-5378

DOI:10.15835/buasvmcn-vm: 12169

\begin{abstract}
Subclinical mastitis is a disease of the udder that passes mostly unnoticed. Or several germs associated with it and their presence in milk constitutes a major risk to consumer health. Our study aims to determine the prevalence of subclinical mastitis in local goats in Laghouat region (Algeria). We undertook a study based on the detection of sub-clinical mastitis by Califirnian Mastitis Test (CMT) in 60 goats aged 1 to 9 years and weighing 18 to $45 \mathrm{~kg}$ of live weight and whose lactation number varies from 2 to 8 . We found a prevalence of subclinical mastitis reaching 46.6\%. A clearly significant difference $(\mathrm{P}<0.05)$ is reported on this prevalence compared to age. The highest rate is recorded especially in goats aged between 3 to 7 years with $62 \%$ of detected subclinical mastitis, followed by the older goats (over 7 years) with a prevalence of $27 \%$, and at the end the youngest goats (1-3 years) with a prevalence of $11 \%$. A significant difference was also recorded between the different lactation ranks $(\mathrm{P}<0.05)$. The goats having the highest rank of lactation were most affected by subclinical mastitis. Prevalence of $46 \%, 31 \%$, $11 \%$ and $8 \%$ respectively are found for the $6^{\text {th }}$ rank of lactation and more, 4 lactations, 5 lactations and 1 lactation. We noticed that the majority of diagnosed mastitis were caused by poor hygiene conditions. This study allows us to conclude that there is a high prevalence of subclinical mastitis in the local goats in the province of Laghouat (Algeria).
\end{abstract}

Keywords: goats, prevalence, sub-clinical mastitis.

\section{INTRODUCTION}

The sub-clinical mastitis is an inflammation of the udder usually associated with a microorganism. The appearance of milk and gland itself is not impaired, but there are changes in the milk composition. The prevalence of clinical mastitis is less than $5 \%$ in goats, while the subclinical mastitis are much more common with a prevalence which ranges from 18 to 34\% (Bauer et al., 1997; Bergonier, 1997; Chingwen et al., 2002). Among the most used for the diagnosis of subclinical mastitis methods, the CMT (Clifornian Mastitis Test).

\section{AIMS AND OBJECTIVES}

Our research aims to determine the prevalence of subclinical mastitis in local goats in Laghouat region (ALGERIA).

\section{MATERIALS AND METHODS}

The experimental herd consists of 60 goats aged 1 to 9 years old, weighing 18 to $45 \mathrm{~kg}$ live weight and whose lactation number varies from 2 to 8 . The screening for subclinical mastitis is performed by the Califirnian Mastitis Test (CMT). The manner of interpretation of CMT results is as follows: See the degree of gelation (formation 
Tab. 1. The CMT interpretation grid (Montaldo and Martinez-Lozano, 1993)

\begin{tabular}{|c|c|c|}
\hline Note & Mixture aspect & Interpretation \\
\hline ‘0’ & No precipitate, oily appearance & Negative \\
\hline '+/-' & Light flocculations disappearing at agitation & Traces \\
\hline '+' & Granular precipitate & Doubtful \\
\hline '++' & Filamentous precipitate & Slightly positive \\
\hline ‘+++' & Viscous precipitate & Very positive \\
\hline
\end{tabular}

Fig. 1. Percentage of mastitis in the tested farms

of flocculant by precipitation of milk mixed with teepol reagent) (Tab. 1).

\section{RESULTS AND DISCUSSION}

We found a prevalence of subclinical mastitis reaching the $46.6 \%$ (Fig. 1).

Prevalence of subclinical mastitis in relation to age: A clearly significant difference $(\mathrm{P}<0.05)$ was found between the different age groups. The highest rate is recorded especially in goats aged between 3 to 7 years with $62 \%$ of detected subclinical mastitis, followed by the older goats (over 7 years) with a prevalence of $27 \%$, and at the end the youngest goats (1-3 years) with a prevalence of $11 \%$.

Prevalence of subclinical mastitis in relation to lactation rank: A significant difference was also recorded between the different lactation ranks ( $\mathrm{P}<0.05)$. The goats having the highest rank of lactation were most affected by subclinical mastitis. Prevalence of $46 \%, 31 \%, 11 \%$ and $8 \%$ respectively are found for the $6^{\text {th }}$ rank of lactation and more, 4 lactations, 5 lactations and 1 lactation. Mibilu et al., 2007 in Tanzania found $76.6 \%$ of subclinical mastitis in goats. Swal et al., 2008 found 51.5\%. Gebrewahid et al., 2012 in Ethiopia report 18\%. Razi et al., 2012 in Bangladesh indicate 18.64\%. The vast majority of sub-clinical mastitis may be due to a lack of hygiene and also to the extensive and traditional type of farming practices.

\section{CONCLUSION}

A high prevalence of subclinical mastitis (46.6\%) exists in goats in Laghouat (Algeria). The highest rates are found at age between 3 and 7 years old but also in females in the fourth rank of lactation and more. The major predisposing factor is the lack of hygiene.

\section{REFERENCES}

1. Bauer A (1997). Weaning food improvement and constraints on its acceptance by rural women in selected villages near the "Station de Recherche Agronomique de Cinzana". -Basel (Suisse): -Novartis Foundation For Sustainable Development.-59p.

2. Bergonier D, Blanc M.C, Fleury B, Lagriffoul G, Barillet F, Berthelot X (1997). Les mammites des ovins et des caprins laitiers. Renc Rech Ruminants, 4 : 251-260.

3. Chingwen Y, Han-tsung W, Jih-tay H (2002). Relationship of somatic cell count, physical, chemical and enzymatic properties to the bacterial standard plate count in dairy goat milk. Livestock Production Science, 74 : 63 - 77.

4. Mibilu TJNK (2007). Status of mastitis in lactating goats at Sokoine University of Agriculture and neighboring small holder farms in Morogoro Municipality, Tanzania. Livestock Res Rural Dev 19(3): 54.60.

5. Swai ES, Mobise E, Mtui PF (2008). Occurrence and factors associated with udder infections in small holder lactating diary goats in Arumeru district, Tanzania, Veterinary Investigation center. Livestock Res Rural Dev 12: 1-12.

6. Gebrewahid T, Abera B.H, Menghistu H.T (2012). Prevalence and Etiology of Subclinical Mastitis in Small Ruminants of Tigray Regional State, North Ethiopia,Veterinary World 5 (2): 103-109

7. Razi KMA, Bahanur Rahman Md, Gerardo H, FloresGutiérrez, Tanvir Rahman Md (2012). Prevalence of Caprine Subclinical Mastitis in Mymensingh Area, Bangladesh and Characterization of Associated Bacterial Agents and the Risk Factors. Microbes and Health 1(1): $1-5$ 